\section{Scientists evaluate potential environmental risks of transgenic crops}

\author{
Norman C. Ellstrand
}

A relatively small group of scientists - including some Californians - have taken a hard and thoughtful look at the potential risks of transgenic crops. These varied scientists - including ecologists, soil biologists, agronomists, geneticists, entomologists, pathologists, horticulturists, botanists and molecular biologists - realize that traditional plant improvement and agriculture have, on occasion, created problems, and those problems can serve as models for anticipating the possible downsides of transgenic crops. A set of straightforward, scientifically based concerns has evolved. The most widely discussed concerns fall into two broad categories: (1) problems created directly by growing the crops themselves, and (2) problems created by unintended descendants of those crops.

Environmental biosafety is a relatively new and rapidly developing research area. An excellent source of information on this field is the National Research Council's (NRC 1989, 2000, $2002,2004)$ series of peer-reviewed reports on the potential environmental impacts of agricultural biotechnology. The most up-to-date information can be found in peer-reviewed, disciplinary journals such as Environmental Biosafety Research, Ecological Applications and Molecular Ecology.

\section{Direct impacts of crops themselves}

Scientific consideration of the direct impacts of transgenic crops has focused almost exclusively on the evolution of pests that are resistant to new strategies for their control, and unwanted impacts on species in associated ecosystems. Another area of concern is the unwanted impacts on surrounding plant and animal communities from the use of transgenic herbicide-resistant plants (Firbank et al. 2003). Resistance to one or more herbicides is a general feature of most crops; also, resistance to herbicides can often be obtained through nontransgenic techniques (Duke et al. 1991). The impact of herbicide-resistant crops on surrounding community diversity depends largely on the type of herbicide, and where and how it is used.

Evolution of resistant pests. Insects, weeds and microbial pathogens often evolve resistance to controls used against them (Barrett 1983; Georghiou 1986; Green et al. 1990). When a pest evolves the ability to attack a crop, the results sometimes can be devastating. The 1970 corn leaf blight epidemic ravaged American cornfields, resulting in the loss of tens of millions of dollars to the industry (NRC 1972).

Resistance evolution is also expected to occur in pests targeted for control by or associated with transgenic crops. Although the evolution of resistance is a continuous process, the evolution of resistant pests has been considered a potential environmental hazard of transgenic crops because more environmentally damaging alternative treatments would then be needed for control. Furthermore, transgenic products at present have resulted in the use of a single, uniform control method over huge areas.

For example, most of the transgenic corn and cotton now grown in the United States, millions of acres, is engineered with a bacterial gene that allows them to manufacture their own pesticide to specifically target certain insect pests. Because the gene comes from the bacterial species known as Bacillus thuringiensis, these plants are commonly known as "Bt corn" and "Bt cotton." Bt cotton is the most important transgenic crop in California (Taylor et al. 2004). Because the transgenic product does not kill all insect species, it is considered relatively environmentally benign. But the evolution of resistance to Bt crops is considered inevitable (NRC 2000). The U.S. Environmental Protection Agency has issued guidelines mandating that farmers plant "refuges" of non-Bt varieties in plantations of Bt varieties to prevent or delay the evolution of resistance. Despite the commercialization of Bt crops for almost a decade, no pests have yet evolved resistance to Bt crops in the field, sug-

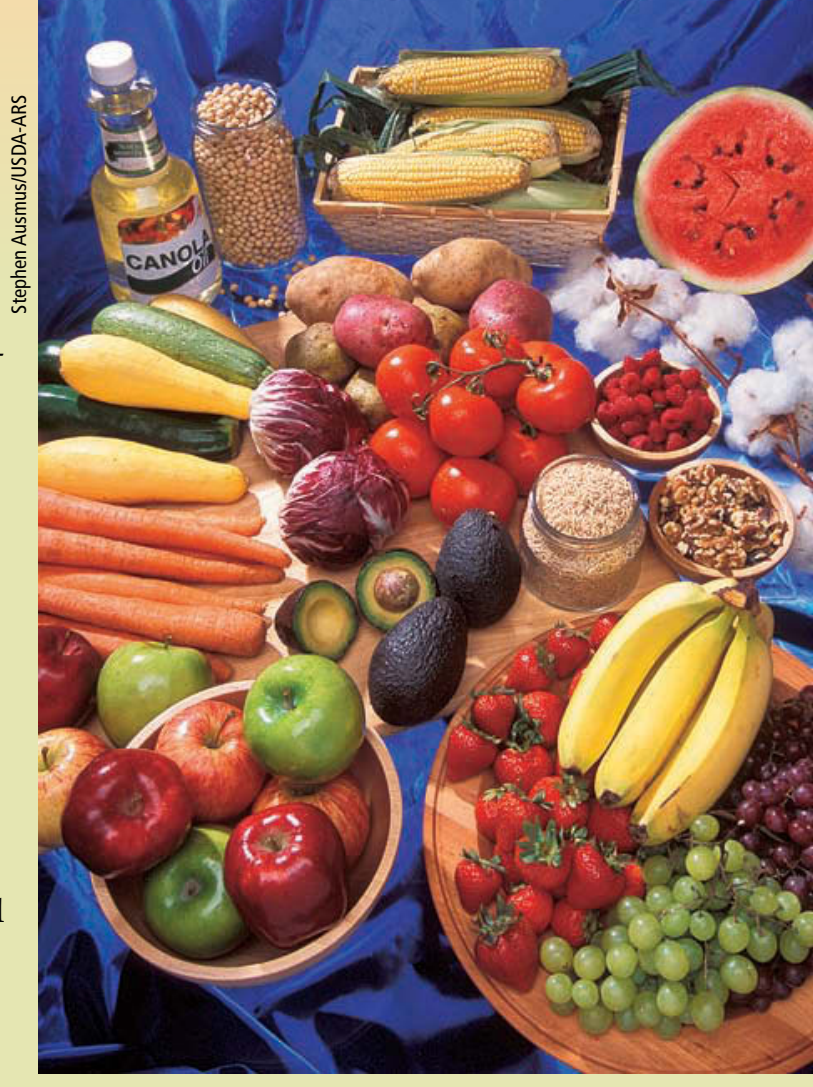

Genetic engineering has been used to modify all of the crops and products shown, although most are not commercially available. The environmental risks of growing transgenic crops could include pest resistance and unintended effects on nontarget species, such as increased weediness among similar wild plants.

gesting that the refuge strategy has been effective (Tabashnik et al. 2003).

Effects on nontarget species. A crop engineered to interfere with the reproduction or viability of one or more pest species might also interfere with other nonpest species. For example, Bt corn was developed to control certain moth species that damage the crop. Reports of potentially toxic effects of Bt corn pollen and flower parts eaten by monarch butterfly larvae captured widespread attention (Losey et al. 1999). A flurry of subsequent research demonstrated that the effects of Bt pollen on monarch larvae are highly variable, depending on factors such as pollen density, the crop's Bt genotype and environmental factors (Sears et al. 2001). Current commercial Bt corn varieties are not considered hazardous to monarch larvae, but one variety no longer grown would have been. This example illustrates that risk assessment research can clarify whether a putative risk is, in fact, a problem.

But is this a new environmental problem? One might ask, "Isn't it better 


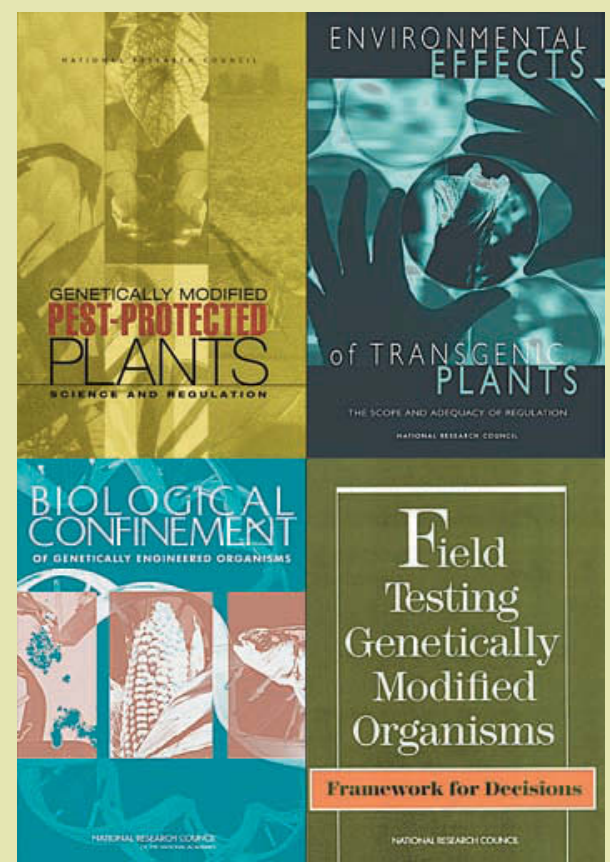

The National Research Council has published numerous science-based reports on the environmental risks and benefits of transgenic plants and food.

to deploy a pesticide through a plant that kills only a subset of insects than to spray one on a field that kills all insects willy-nilly?" The answer, of course, would be, "Yes, Bt in corn reduces environmental impacts relative to spraying broad-spectrum insecticides." However, prior to the advent of Bt corn, many American corn farmers did not spray insecticides to control the pests controlled with Bt (NRC 2000). Those farmers simply took their chances without any control, possibly because the damage from the lepidopteran pests of corn varies so much from one year to the next. In the latter comparison, the addition of $\mathrm{Bt}$, if it carries adverse nontarget effects, does pose a new problem.

\section{Unintended crop descendants}

All plants - including crops - are capable of some type of reproduction. The possibility of unintended reproduction by transgenic crops has raised questions about whether their descendants might cause problems. These problems have fallen into two broad categories: first, that the direct feral descendants of the crops may prove to be new weeds or invasives, and second, that unintended hybrids between transgenic crops and other plants could lead to certain problems.

\section{If deregulated and grown widely, these potential future crops will require further scrutiny for possible gene-flow problems.}

Progeny of the transgenic crop could become a problem if the transgenic trait alters their ecological performance such that they evolve increased aggressiveness. Some crop plants - especially those with a long history of domestication (e.g., corn and soybeans) - pose little hazard because traits that make them useful to humans also reduce their ability to establish feral populations in either agroecosystems or nonagricultural habitats (NRC 1989). But other cultivated plants (e.g., certain forage grasses and turf grasses, ornamentals, rice, rye, alfalfa) often volunteer after cultivation, founding feral populations that create problems (Gressel 2005). In some cases, the tendency to found feral populations could increase as the result of acquiring new traits.

The factors that foster or limit invasiveness are not well understood (Sakai et al. 2001). Most of the current transgenic crop traits - insect, virus and herbicide resistance - are expected to confer a fitness advantage in certain environments. Empirical evolutionarygenetics studies have demonstrated that a new allele that confers a fitness advantage will usually spread rapidly through a population, but it will not necessarily result in the evolution of invasiveness (Bergelson 1994). The mere presence of a transgene that increases fitness cannot be taken as certainty that the invasiveness of a population has increased. Many crops are unlikely to become weedier by the addition of a single trait (Keeler 1989). In a few cases, however, the consequences might be obvious. The evolution of herbicide resistance in a weed population that was previously controlled by that chemical will force the consideration of new control options.

\section{Scientifically based assessment}

Genetically engineered crops are a heterogeneous group. It is no more reasonable to lump them all together to argue that, as a group, they pose an environmental danger than it is to lump them all together to argue that, as a group, they will feed the world and cure disease. It is fair to say that just like the products of traditional plant improvement, certain products of genetic engineering will create problems. To the extent that those products can be compared to traditionally improved plants, scientifically based hazards can be identified.

\section{References}

Barrett SCH. 1983. Crop mimicry in weeds. Econ Botany 37:255-82.

Bergelson J. 1994. Changes in fecundity do not predict invasiveness: A model study of transgenic plants. Ecology 75:249-52.

Duke SO, Christy AL, Hess FD, Holt JS. 1991. Herbicide-Resistant Crops. Council for Agricultural Science and Technology, Ames, IA. 24 p.

Firbank LG, Heard MS, Woiwod IP, et al. 2003. Methodological insights: An introduction to the farmscale evaluations of genetically modified herbicidetolerant crops. J Applied Ecol 40:2-16.

Georghiou G. 1986. The magnitude of the resistance problem. In: Pesticide Resistance: Strategies and Tactics for Management. Washington, DC: Nat Acad Pr. p 14-43. 471 p.

Green MB, LeBaron H, Moberg, WK. 1990. Managing Resistance to Agrochemicals: From Fundamental Research to Practical Strategies. American Chemical Society Symposium Series, No 421.

Gressel J. 2005. Crop Ferality and Volunteerism. Boca Raton, FL: CRC Pr. 448 p.

Keeler KH. 1989. Can genetically engineered crops become weeds? Biotechnology 7:1134-9.

Losey JE, Rayor LS, Carter ME. 1999. Transgenic pollen harms monarch larvae. Nature 3999:214.

[NRC] National Research Council. 1972. Genetic Vulnerability of Major Crops. Washington, DC: Nat Acad Pr. 307 p.

NRC. 1989. Field-testing Genetically Modified Organisms: Framework for Decisions. Washington, DC: Nat Acad Pr. $170 \mathrm{p}$.

NRC. 2000. Genetically Modified Pest-Protected Plants: Science and Regulation. Washington, DC: Nat Acad Pr. $261 \mathrm{p}$

NRC. 2002. Environmental Effects of Transgenic Plants: The Scope and Adequacy of Regulation. Washington, DC: Nat Acad Pr. 320 p.

NRC. 2004. Biological Confinement of Genetically Engineered Organisms. Washington, DC: Nat Acad Pr. $255 \mathrm{p}$.

Sakai AK, Allendorf FW, Holt JS, et al. 2001. The population biology of invasive species. Ann Rev Ecol Systematics 32:305-32.

Sears MK, Hellmich RL, Stanley-Horn DR, et al. 2001. Impact of Bt corn pollen on monarch butterfly populations: A risk assessment. Proc Nat Acad Sci 98:11937-42.

Tabashnik BE, Carrière Y, Dennehy TJ, et al. 2003 Insect resistance to Bt crops: Lessons from the first seven years. ISB News Report (Nov): 1-4.

Taylor MR, Tick JS, Sherman DM. 2004. Tending the Fields: State \& Federal Roles in the Oversight of Genetically Modified Crops. Pew Initiative on Food and Biotechnology, Washington, DC. 157 p. 
- continued from page 118

beet fields (Bartsch and Ellstrand 1999). Likewise, genetic analysis of putative spontaneous hybrids has demonstrated that cultivated grape mates with wild grape species in California (Olmo and Koyama 1980). The data from such descriptive studies and experiments provides ample evidence that if cultivated plants and their wild relatives occur in close proximity, occasional spontaneous hybridization is not unusual. This phenomenon is a general feature of most of the world's important crops, from avocado to corn, and soybean to mushrooms (Ellstrand 2003b; den Nijs et al. 2004). Even the sorghum-johnsongrass results, involving a crop so different from a wild relative that their chromosome numbers are different, have not been shown to be an exceptional case.

\section{Impacts of natural hybridization}

When I gave seminars on the results of these studies, I was met by a new question: "If gene flow from crops to their wild relatives is going to be a problem for crops improved by genetic engineering, then wouldn't such problems already have occurred for species improved by traditional, nontransgenic methods?" A good question. I conducted a thorough literature review to find out what was known about the consequences of natural hybridization between the world's most important crops and their wild relatives, a multiyear odyssey of digging through diverse literature and interviewing dozens of the world's experts on important crops and their wild relatives (Ellstrand 2003b).

I found that on occasion, crop-toweed gene flow has created hardship through the appearance of new or more-difficult weeds. Hybridization between wild plants and their cultivated relatives has been implicated numerous times in the evolution of new weeds or the evolution of increased weediness in pre-existing weeds (Ellstrand 2003b). Especially notable is Europe's new weed beet, the spontaneous hybrids between sea beet (Beta vulgaris subsp. maritima) and sugarbeet (B. vulgaris subsp. vulgaris) and their descendants. This weed has cost Europe's sugar industry well over a billion dollars in reduced yields, damaged machinery and control costs (den

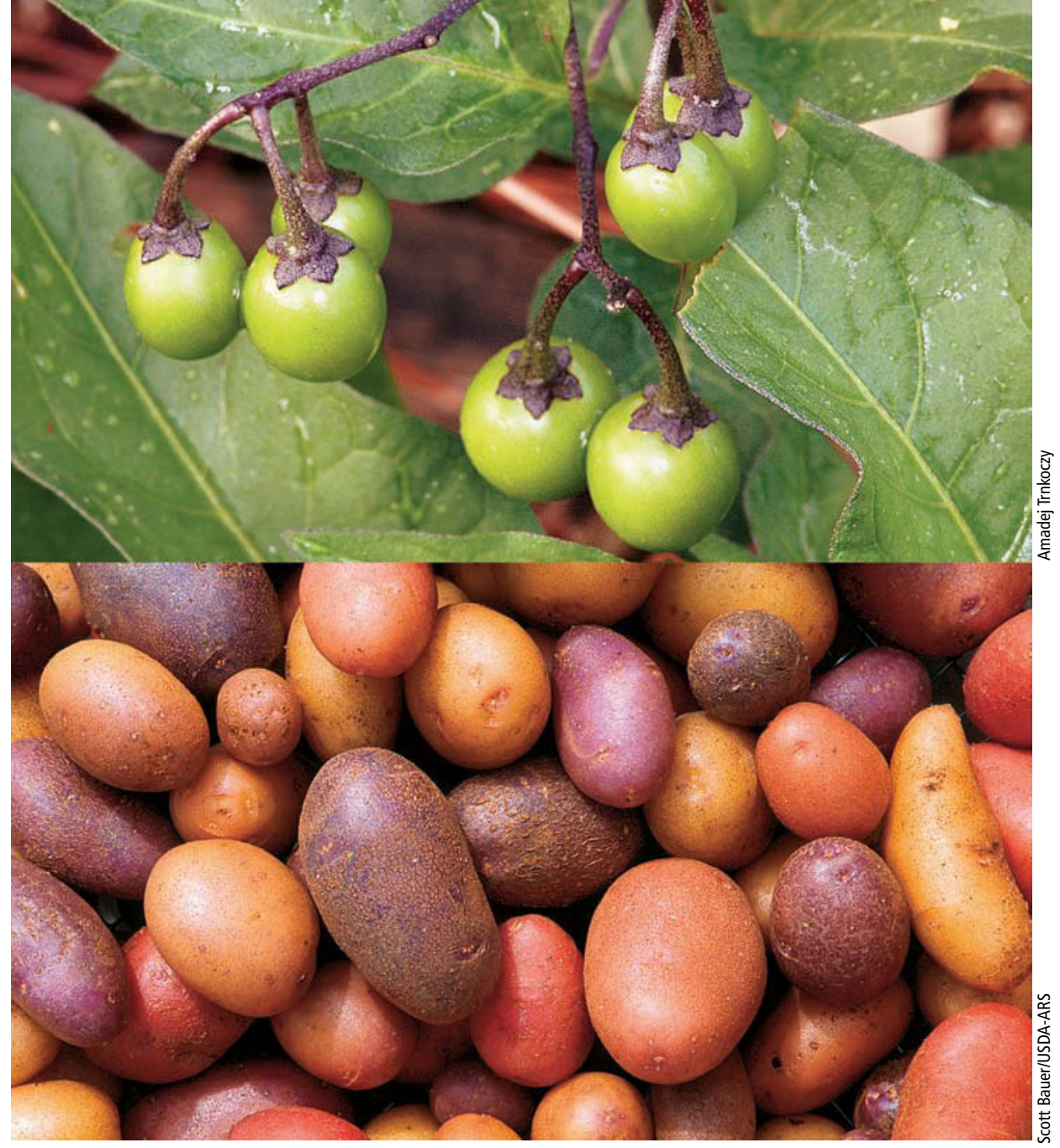

While crop-to-wild plant gene flow has been widely documented in numerous combinations, an exception is, bottom, potato (Solanum tuberosum), which does not naturally cross with the wild related species, top, European bittersweet (Solanum dulcamara) under field conditions.

Nijs et al. 2004; Ellstrand 2003b; Parker and Bartsch 1996).

Crop-to-wild gene flow can create another problem. Theoretical models have demonstrated that hybridization between a common species and a rare one can, under the appropriate conditions, send the rare species to extinction in a few generations (Ellstrand and Elam 1993; Huxel 1999; Wolf et al. 2001). In several cases, hybridization between a crop and its wild relatives has increased the extinction risk for the wild taxon (Ellstrand 2003b). One example is the extinction of a wild subspecies of rice in Taiwan (Kiang et al. 1979). Furthermore, Ledig (1992) reported that in California, "pollen contamination from cultivated walnut may hybridize the (endangered) Hinds walnut out of existence."

The vast majority of cases of spontaneous hybridization between cultivated plants and their wild relatives are of little consequence. But clearly gene flow from crops to wild relatives has, on occasion, had undesirable consequences.
Are transgenic crops likely to be different from traditionally improved crops? No, but that is not necessarily good news. The probability of problems due to gene flow from any individual cultivar is extremely low. But when those problems are realized, they can sometimes be costly.

\section{New transgenic cultivars}

As a group, new transgenic cultivars are no more or less likely to hybridize than their nontransgenic counterparts (Ellstrand 2003b; den Nijs et al. 2004). Whether transgenic crops are more or less likely to create gene-flow problems will depend in part on their phenotypes, the traits for which they were engineered. The majority of "first generation" transgenic crops have phenotypes - such as herbicide or pest resistance - that are apt to give a weed a fitness boost in certain environments. Although a fitness boost in itself may not lead to increased weediness, scientists engineering crops with such traits 
TABLE 1. Transgenic crops approved for field-testing in California through Jan. 16, 2006*

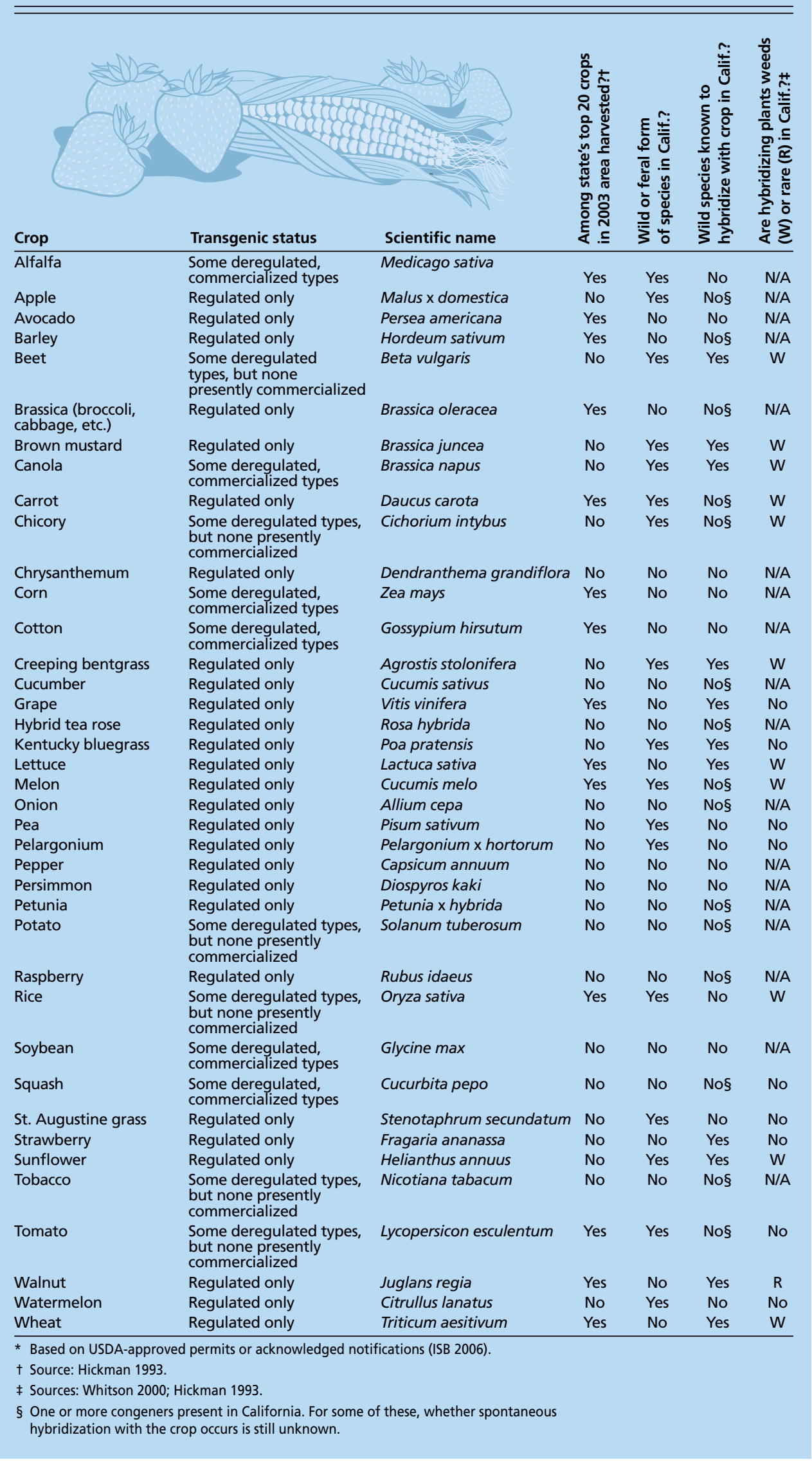

should be mindful that those phenotypes might have unwanted effects in natural populations.

The crops most likely to increase the extinction risk by gene flow are those planted in new locations that bring them into the vicinity of wild relatives, thereby increasing the hybridization rate because of proximity. For example, a new variety with increased salinity tolerance might be planted within the range of an endangered salt-tolerant relative. It is clear that scientists creating new crops for field release, transgenic or otherwise, should consider the possibility of gene flow when making choices about whether it might create problems, and if so, how to create the best and safest products (NRC 2004).

\section{Risks to California}

But how likely is it that transgenes will flow to wild plants in California? At the moment, only seven different crops with genetically engineered varieties are commercially available in the United States: canola, corn, cotton, papaya, soybean, squash and tobacco. In California, five of these have no closely related wild relatives: corn, cotton (California's primary transgenic crop), papaya (which cannot be grown outdoors in California) and squash. These plants do not even establish feral populations in California. Furthermore, transgenic tobacco is not grown in California. For these six crops, gene flow into the wild in California is not possible. (As this article is going to press, genetically engineered alfalfa was deregulated for probable commercialization in California.)

Transgenic canola (Brassica napus) or "oilseed rape" is a different story. A tremendous amount of interspecies gene-flow research, both descriptive and experimental, has been conducted on this species in the United States, Canada, United Kingdom, France and Denmark (Ellstrand 2003b; den Nijs et al. 2004). Brassica napus naturally and easily intermates with wild $B$. rapa and, to a much more limited extent, with a few other mustard family species. Most of those species, including B. rapa, occur in California where they are known to be problematic weeds (Whitson 2000). Experiments have demonstrated that the hybrids between canola and 


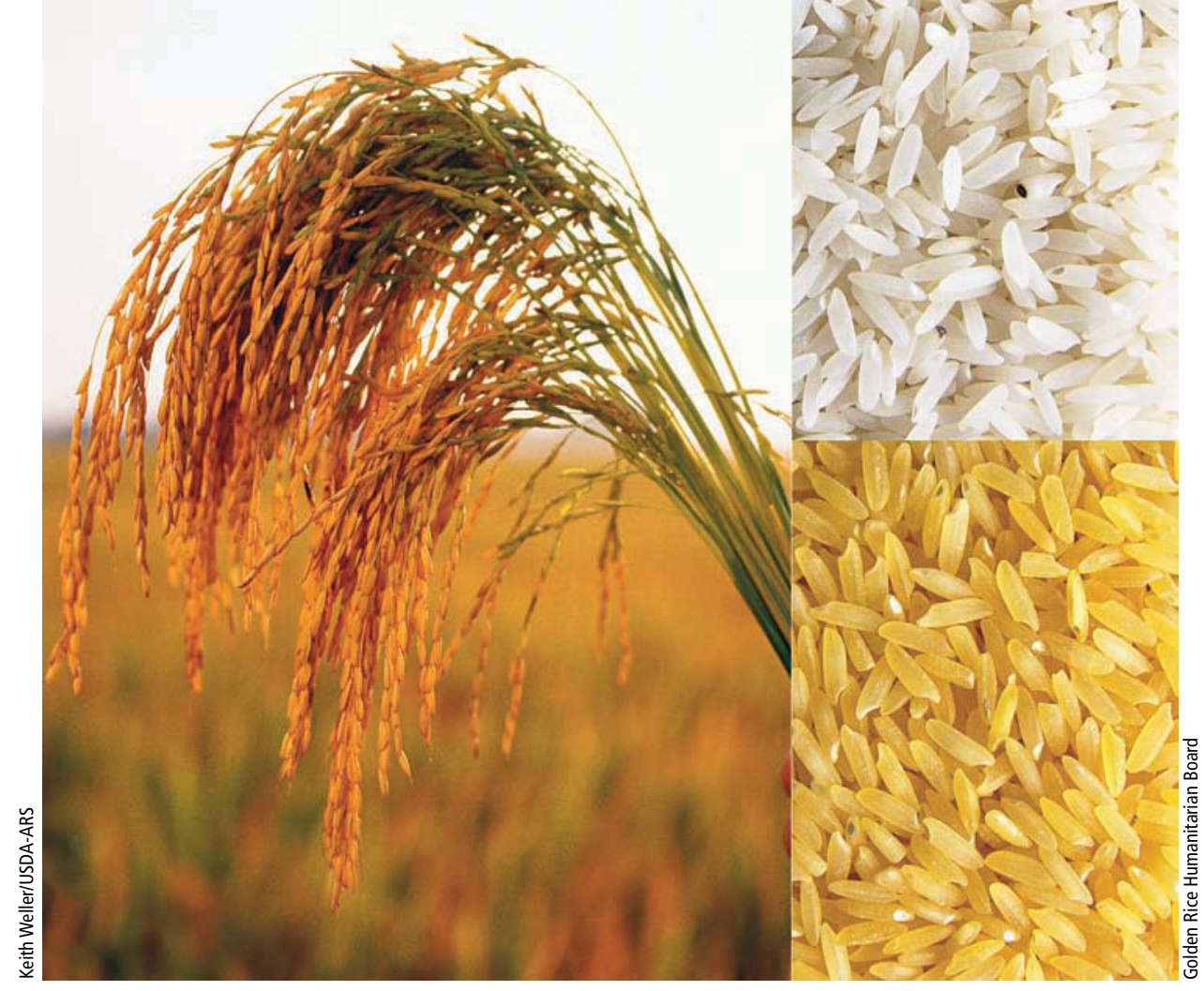

from fungal-disease-resistant avocado to pharmaceutical-producing rice.

More than half of the 39 fieldtested crops have wild relatives in the California flora with which they are capable of hybridizing - either as wild plants that are same species or as closely related species known to spontaneously hybridize with the crop (table 1). In 11 cases, those wild plants are considered weeds in California. Fourteen of the field-tested crops rank among the top 20 California crops in terms of acreage harvested; 10 have cross-compatible mates in the wild flora of California. If deregulated and grown widely, these potential future crops will require further scrutiny for possible gene-flow problems. For example, wheat spontaneously hybridizes with a number of known weeds in the genus

Due to market concerns, California rice growers are cautious about adopting transgenic crops that could cross with conventional varieties. Left, U.S. long-grain rice and, top right, rice grains. Lower right, "golden rice" is genetically engineered to accumulate pro-vitamin A in the grain, in order to help fight nutritional deficiency diseases in developing countries.
B. rapa typically have a drop in fitness relative to their parents, but that fitness is rapidly regained when those hybrids mate with one another or backcross to either parent. Only two genetically engineered types of canola are commercially available in the United States: plants engineered with resistance to the herbicide glyphosate and those engineered with resistance to the herbicide glufosinate.

Interestingly, the first and only reported case of spontaneous hybridization between a commercial transgenic crop and a wild relative involved genetically engineered glyphosateresistant canola and B. rapa, in Quebec (Warwick et al. 2003). The hybrid plants were found where the wild species were growing in or adjacent to glyphosate-resistant canola.

The appearance of glyphosate resistance in B. rapa could present a problem if it forces farmers - who control this weed with relatively inexpensive and relatively environmentally benign glyphosate - to abandon it in favor of an alternative herbicide without those benefits. Whether or not the Quebec hybrids become a problem is currently under study by the group that discovered them. However, canola is not an impor- tant, or even significant, California crop. Furthermore, the adoption of transgenic canola has not been nearly as enthusiastic in the United States as it has been for soybeans, corn and cotton. The majority of the U.S. canola crop remains nontransgenic. Therefore, the opportunities for the canola transgene to spread in California are much more limited than in Canada, where it is one of the most important crops.

\section{The future of plant biotech}

The face of plant biotechnology is rapidly changing. Dozens of genetically engineered crop species have been fieldtested. Crops field-tested under U.S. Department of Agriculture/Animal and Plant Health Inspection Service (USDAAPHIS) notification or permit are required to be grown with some level of containment (NRC 2002). If the growers comply with those regulations, fieldtests should not present an opportunity for transgene escape. Nonetheless, such crops represent the pool for new commercial transgenic crops of the next decade. As of Jan. 16, 2006, 1,215 field-test applications had been approved for 39 crops in California (table 1) (ISB 2006). The applications are for hundreds of different crop-trait combinations, Aegilops that grow wild in California. Whether the movement of transgenes into the wild will create problems depends on the specific transgenic-based trait and how it is expressed in the wild populations (Ellstrand 2003b).

Compared to crop-to-wild transgene movement, crop-to-crop movement is much more likely. Different varieties of the same crop are usually fully sexually compatible. It is not unusual for adjacent and simultaneously flowering fields of the same crop to cross-pollinate. Also, gene flow by seed becomes an issue in this context. Unless very carefully segregated, seed from different varieties often becomes mixed during seed production. If a seed bank persists in the soil, individuals from last year's planting can appear within this year's crop. If a transgene moves unintended from one field of a crop to another of the same crop, a number of adverse consequences are possible, including: the loss of security for intellectual property; effects on nontarget organisms in natural or agroecosystems; and the evolution of new weeds.

\section{Genetic pollution of crops}

"Genetic pollution" may occur in crops intended to have a certain level of purity with regard to market demands - for example, crops certified as organic or intended for foreign markets that do not tolerate the presence of materials from genetically engineered plants. Health effects may be possible if genes engineered 
to produce pharmaceutical or industrial compounds enter the food or feed supply. Such plants are required to be grown only under stringent field-test regulations. However, lack of compliance (NRC 2004; Taylor and Tick 2003) can create opportunities for such genes to move. Little has been written regarding the possible downsides of crop-to-crop gene flow involving transgenic plants, but recent incidents suggest that much more attention should be paid to this risk.

Herbicide resistance in canola. For example, multiple herbicide resistance developed in canola in Alberta, Canada (Hall et al. 2000). Volunteer canola plants were found to be resistant to two or more of the following herbicides: glyphosate (Roundup: Monsanto, St. Louis; Mo.), glufosinate-ammonium (Liberty: Aventis Crop Science, Research Triangle Park, N.C.) and imazethapyr (Pursuit: BASF, Research Triangle Park, N.C.). Clearly, multiple hybridization events among three different canola varieties were necessary to account for these genotypes. The alleles for resistance to glyphosate and glufosinateammonium are transgenes, but the allele for imazethapyr resistance is the result of mutation breeding. Although these volunteers can be managed with other herbicides, this report is signifi- cant because it illustrates that gene flow into wild plants is not the only avenue for the evolution of plants that are increasingly difficult to manage.

Starlink corn. A better-known incident involved Starlink corn (NRC 2004; Taylor and Tick 2003). The Starlink gene and its product were approved only for animal feed, not human consumption. However, Starlink's genetically engineered protein appeared in a variety of products intended for human consumption. USDA detected the protein in over $10 \%$ of the corn samples initially screened, none of which were supposed to contain Starlink material. Although unintentional mixing of seeds during transport or storage may explain the unexpected presence of the unapproved transgenic product in the human food supply, intervarietal cross-pollination between adjacent cornfields probably played an important role as well. The story is significant because it illustrates how easy it is to lose track of transgenes. Without careful confinement and monitoring, there are plenty of opportunities for them to move from variety to variety (Christensen et al. 2005; NRC 2004).

If the two preceding incidents were the only examples of transgenes showing up where they shouldn't, they could be considered anomalous. But they are only

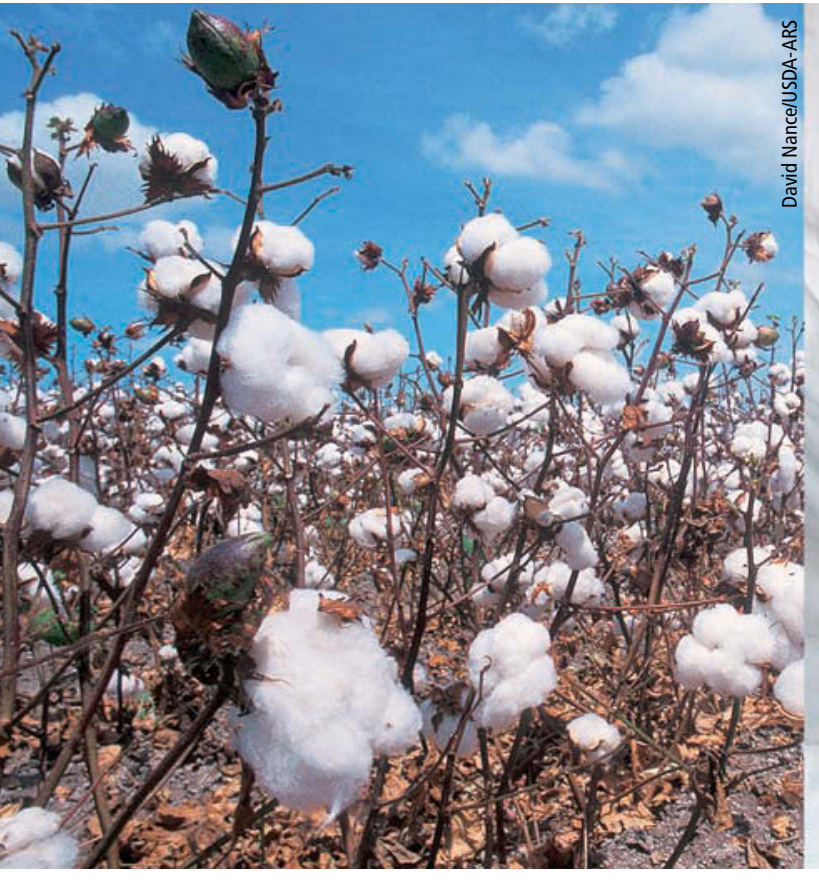

While organic crops must be transgene-free, cross-contamination of organic cotton by transgenic varieties is not expected to be a problem because seeds (which may contain genes from an engineered pollen parent) are removed from the lint (which is pure maternal tissue). Left, a cotton crop; right, baby clothes made with organic cotton. a tiny sample of an increasing number of such events. For a decade, more than a dozen cases of transgenes and/or their products out-of-place have been reported (Marvier and Van Acker 2005).

Gene flow in itself is not necessarily a problem, but unless specific steps are taken to isolate transgenic crops, the movement of transgenes to nontransgenic crops should not be an unusual occurrence. In fact, the frequency of these events has led some scientists to write, "the movement of transgenes beyond their intended destination is a virtual certainty" (Marvier and Van Acker 2005).

\section{A problem for California?}

Organic farming. If crop-to-crop gene flow is a "virtual certainty," which of its possible downsides are more likely to prove to be a problem in California? The issue of "coexistence" of genetically engineered crops with organic farming may be the most important (Schiemann 2003). The organic sector of California agriculture is rapidly growing. Organic crops are required to be transgene free. Presently, the onus for isolation is put on the organic grower. If transgenic crops pollinate organic crops, then their seed will bear transgenes. Of California's current major transgenic crops, this would not pose a problem for organic cotton because the seeds are removed from the lint, which is maternal tissue; on the other hand, farmers growing organic corn would have to practice some form of isolation to prevent them from being pollinated by nearby transgenic fields. Seed-source purity would be an important factor for growers of either organic cotton or organic corn. As more crops are deregulated and grown in California, the issue will continue to grow, especially for crops that are widely planted in the state.

Pharmaceutical crops. Transgenic crops that are grown to produce pharmaceutical and other industrial biochemicals pose another potential problem. These will pose special challenges for containment if we do not want those chemicals appearing in the human food supply. In the last 5 years, nine field-test applications of such plants were approved for California.

We know that it is easy to lose track of transgenic genes - if pollen moves 
farther than expected, if seeds stay in the soil ungerminated or if seed are inadvertently mixed. The mixing of genes between different varieties of the same crop is a lot easier than the flow of genes into the wild, but both can have their downsides.

\section{Weighing risks and benefits}

In most cases, transgenes will not need to be contained. But sometimes containment will be helpful or necessary. New methods must be developed because present agronomic protocols are not always sufficient to do the job. New segregation procedures are being proposed (Christensen et al. 2005; Strayer 2002). Likewise, engineered constructs and other genetically based methods are being studied to effect containment (NRC 2004). All of these methods seem promising and need to be tested.

In the meantime, the creators of transgenic plants need to be as mindful of possible problems with their products as they are of potential promise. The best confinement should be upfront, with decisions made at the start of a project. In at least three cases that this author is aware of, scientists decided to stop engineering certain traits into certain crops because of anticipated problems with gene flow. But stopping a project altogether may be unnecessary. Often, a good decision will involve consideration of the safest combination of trait and organism. At one time corn was the organism of choice as a "pharm" plant. Today other plant species, often nonfood species, are being explored for this use.

The products of traditional plant improvement are not absolutely safe, and we cannot expect transgenic crops to be absolutely safe either. If we have advanced tools for creating novel agricultural products, we should use the advanced knowledge from ecology and population genetics - as well as social sciences and humanities - to make mindful choices about creating products that are best for us and our environment.

N.C. Ellstrand is Director, Biotechnology Impacts Center, and Professor of Genetics, Department of
Botany and Plant Sciences, UC Riverside. An earlier article (Ellstrand 2001), which reported research that formed the basis for sections of this manuscript, was written with support from the U.S. Department of Agriculture (USDA) (grant no. 0033120-9801). This article was written with support from USDA Biotechnology Risk Assessment Research Grant 2002-12769 and National Science Foundation Biocomplexity Grant DEB-0409984.

\section{References}

Anderson E. 1949. Introgressive Hybridization. New York: Wiley. $109 \mathrm{p}$.

Arriola PE, Ellstrand NC. 1996. Crop-to-weed gene flow in the genus Sorghum (Poaceae): Spontaneous interspecific hybridization between johnsongrass, Sorghum halepense, and crop sorghum, S. bicolor. Am J Botany 83:1153-60.

Arriola PE, Ellstrand NC. 1997. Fitness of interspecific hybrids in the genus Sorghum: Persistence of crop genes in wild populations. Ecol Appl 7:512-8

Bartsch D, Ellstrand NC. 1999. Genetic evidence for the origin of Californian wild beets (genus Beta). Theoretic Appl Genetics 99:1120-30.

Christensen PJ, Misra MK, Rai S, et al. 2005. Confined Production: Processes for Non-Food Corn. Biosafety Institute for Genetically Modified Agricultural Products. Iowa State University, Ames, IA. 81 p.

Colwell RE, Norse EA, Pimentel D, et al. 1985. Genetic engineering in agriculture. Science 229:111-2

Dale PJ, Clarke B, Fontes EMG. 2002. Potential for the environmental impact of transgenic crops. Nature Biotech 20:567-74.

Den Nijs HCM, Bartsch D, Sweet J. 2004. Introgression from Genetically Modified Plants into Wild Relatives. Wallingford, UK: CABI Pub. 403 p.

Ellstrand NC. 2001. When transgenes wander, should we worry? Plant Physiol 125:1543-5.

Ellstrand NC. 2003a. Current knowledge of gene flow in plants: Implications for transgene flow. Philosoph Transactions Royal Soc London B 358:1163-70.

Ellstrand NC. 2003b. Dangerous Liaisons? When Cultivated Plants Mate with Their Wild Relatives. Baltimore, MD: Johns Hopkins Univ Pr. 244 p.

Ellstrand NC, Elam DR. 1993. Population genetic consequences of small population size: Implications for plant conservation. Ann Rev Ecol Systematics 24:217-42

Fehr WR. 1987. Principles of Cultivar Development (Vol. 1): Theory and Technique. New York: Macmillan. $563 \mathrm{p}$.

Goodman RM, Newell N. 1985. Genetic engineering of plants for herbicide resistance: Status and prospects. In: Halvorson HO, Pramer D, Rogul M (eds.). Engineered Organisms in the Environment: Scientific Issues. Washington, DC: Am Soc Microbiol. p 47-53.

Hails RS. 2000. Genetically modified plants: The debate continues. Trends Ecol Evolu 15:14-8.

Hall L, Topinka K, Huffman J, et al. 2000. Pollen flow between herbicide-resistant Brassica napus is the cause of multiple-resistant $B$. napus volunteers. Weed Science 48:688-94.

Hickman JC. 1993. The Jepson Manual. Berkeley,

\section{CA: UC Pr. 1424 p.}

Huxel GR. 1999. Rapid displacement of native species by invasive species: Effect of hybridization. Biologic Conserv 89:143-52.

[ISB] Information Systems for Biotechnology. 2006. Field-test Releases in the U.S. National Biological Impact Assessment Program. USDA Cooperative State Research Education, and Extension Service. www.isb.vt.edu/cfdocs/fieldtests1.cfm.
Kiang YT, Antonovics J, Wu L. 1979. The extinction of wild rice (Oryza perennis formosana) in Taiwan. J Asian Ecol 1:1-9.

Klinger T, Elam DR, Ellstrand NC. 1991. Radish as a model system for the study of engineered gene escape rates via crop-weed mating. Conserv Biol 5:531-5.

Klinger T, Ellstrand NC. 1994. Engineered genes in wild populations: Fitness of weed-crop hybrids of radish, Raphanus sativus L. Ecologic Applica 4:117-20.

Ledig FT. 1992. Human impacts on genetic diversity in forest ecosystems. Oikos 63:87-108.

Marvier M. 2001. Ecology of transgenic crops. Am Scientist 89:160-7.

Marvier M, Van Acker RC. 2005. Can crop transgenes be kept on a leash? Frontiers Ecol Environ 3:99-106.

McPartlan HC, Dale PJ. 1994. An assessment of gene transfer by pollen from field-grown transgenic potatoes to non-transgenic potatoes and related species. Transgen Res 3:216-25.

Nickson TJ, Head GP. 1999. Environmental monitoring of genetically modified crops. J Environ Monitor $1: 101 \mathrm{~N}-5 \mathrm{~N}$.

[NRC] National Research Council. 1989. Field-testing Genetically Modified Organisms: Framework for Decisions. Washington, DC: Nat Acad Pr. 170 p.

NRC. 2000. Genetically Modified Pest-protected Plants: Science and Regulation. Washington, DC: Nat Acad Pr. $261 \mathrm{p}$

NRC. 2002. Environmental Effects of Transgenic Plants. Washington, DC: Nat Acad Pr. 320 p

NRC. 2004. Biological Confinement of Genetically Engineered Organisms. Washington, DC: Nat Acad Pr. $255 \mathrm{p}$.

Olmo HP, Koyama A. 1980. Natural hybridization of indigenous Vitis californica and $V$. girdiana with cultivated vinifera in California. Proc Third Int Symp Grape Breeding, UC Davis. p 31-41.

Parker IM, Bartsch D. 1996. Recent advances in ecological biosafety research on the risks of transgenic plants: A transcontinental perspective. In: Tomiuk J, Wohrmann K, Sentker A (eds.). Transgenic Organisms: Biological and Social Implications. Basel, Switz. Birkhauser Verlag. p 147-61.

Rissler J, Mellon M. 1996. The Ecological Risks of Engineered Crops. Cambridge, MA: MIT Pr. 168 p.

Schiemann J. 2003. Co-existence of genetically modified crops with conventional and organic farming Environ Biosafety Res 2:213-7.

Scientists' Working Group on Biosafety. 1998 Manual for Assessing Ecological and Human Health Effects of Genetically Engineered Organisms (Vols. 1 and 2). Edmonds, WA: Edmonds Inst. 403 p.

Snow AA, Andow DA, Gepts P, et al. 2005. Genetically engineered organisms and the environment Current status and recommendations. Ecolog App 15:377-404

Strayer D. 2002. Identity Preserved Systems: A Reference Handbook. Boca Raton, FL: CRC Pr. 236 p.

Taylor MR, Tick JS. 2003. Post-Market Oversight of Biotech Foods. Pew Initiative on Food and Biotechnology, Washington, DC. 128 p.

Warwick SI, Simard M-J, Légère A, et al. 2003. Hybridization between transgenic Brassica napus L., and its wild relatives: Brassica rapa L., Raphanus raphanistrum L., Sinapis arvensis L., and Erucastrum gallicum (Willd.) O.E. Schulz. Theoretic Applied Genetics 107:528-39.

Whitson TD (ed.). 2000. Weeds of the West (9th ed.). Western Society of Weed Science, Newark, CA. $628 \mathrm{p}$.

Wolf DE, Takebayashi N, Rieseberg LH. 2001. Predicting the risk of extinction through hybridization. Conserv Biol 15:1039-53.

Wolfenbarger LL, Phifer PR. 2000. The ecological risks and benefits of genetically engineered plants. Science 290:2088-93. 